\title{
ON SOME INEQUALITIES OF CHEBYSHEV TYPE
}

\section{ANDRIY L. SHIDliCH AND StAnislav O. CHAICHENKO}

Abstract. We obtain some new inequalities of Chebyshev Type.

Mathematics subject classification (2010): 26D15.

Keywords and phrases: Inequalities, Chebyshev's inequality, monotone functions, convex function.

\section{REFERENCES}

[1] P. L. Chebyshev, O priblizhennyh vyrazhenijah odnih integralov cherez drugie, Soobschenija i Protokoly Zasedanij Matematicheskogo Obschestva pri Imperatorskom Khar'kovskom Universitete, No. 2 (1882), 93-98; Polnoe Sobranie Sochinenii P. L. Chebysheva, Moskva-Leningrad, 3, (1978), 128-131.

[2] P. L. CHEBYSHEV, Ob odnom rjade, dostavljajuschem predel'nye velichiny integralov pri razlozhenii podintegral'noi funkcii na mnozhiteli, Prilozhenie k 57 tomy Zapisok Imp. Akad. Nauk, No. 4 (1883); Polnoe Sobranie Sochinenii P. L. Chebysheva. Moskva-Leningrad, 3, (1978), 157-169.

[3] H. P. Heinig And L. Maligranda, Chebyshev inequality in function spaces, Real Anal. Exchange, 17, 1 (1991/92), 211-247.

[4] D. S. MitrinoviĆ AND J. E. PeČARIĆ, History, variations and generalisations of the Čebyšev inequality and the question of some priorities II, Rad JAZU (Zagreb), 450, 9 (1990), 139-156.

[5] D. S. Mitrinović, J. E. PeČArić, A. M. Fink, Classical and new inequalities in analysis, Kluwer, 1993.

[6] D. S. MitrinoviĆ AND P. M. VASIĆ, History, variations and generalisations of the Čebyšev inequality and the question of some priorities, Univ. Beograd. Publ. Elektrotehn. Fak. Ser. Mat. Fiz. 461-497, (1974), 1-30.

[7] A. L. SHidLich, On necessary and sufficient for validity of some Chebyshev-Type inequalities, J. Math. Inequal., 5, 1 (2011), 71-85.

[8] J. F. StefFensen, En Ulighted mellem Middelve edier, Mat. Tidsskrift, B, (1920), 49-53. 